\title{
Erratum
}

\section{Common genetic polymorphisms in the promoter of resistin gene are major determinants of plasma resistin concentrations in humans}

\author{
Y. M. Cho', 2 - B.-S. Youn ${ }^{3}$ S. S. Chung ${ }^{2}$ K. W. Kim ${ }^{2} \cdot$ H. K. Lee ${ }^{1}$ K.-Y. Yu ${ }^{3}$ H. J. Park ${ }^{3}$ H. D. Shin ${ }^{4}$ \\ K. S. Park 1,2 \\ ${ }^{1}$ Department of Internal Medicine, Seoul National University College of Medicine, Seoul, Korea \\ ${ }^{2}$ Genome Research Center for Diabetes and Endocrine Disease, Clinical Research Institute, Seoul National University Hospital, \\ Seoul, Korea \\ ${ }^{3}$ KOMED Institute for Life Science, Graduate School of Biotechnology, Korea University, Seoul, Korea \\ ${ }^{4}$ Department of Genetic Epidemiology, SNP Genetics, Seoul, Korea
}

\section{Diabetologia (2004) 47:559-565}

Figure 1a. The correct positions of the arrows for Band 1 and Band 2 are shown below:
Published online: 25 June 2004

(C) Springer-Verlag 2004

K. S. Park (®)

Department of Internal Medicine,

Seoul National University College of Medicine,

28 Yongon-Dong Chongno-Gu, Seoul, 110-744 Korea

E-mail: kspark@snu.ac.kr

The online version of the original article can be found at http://dx.doi.org/10.1007/s00125-004-1319-x 
a

g. $-420 C>G$

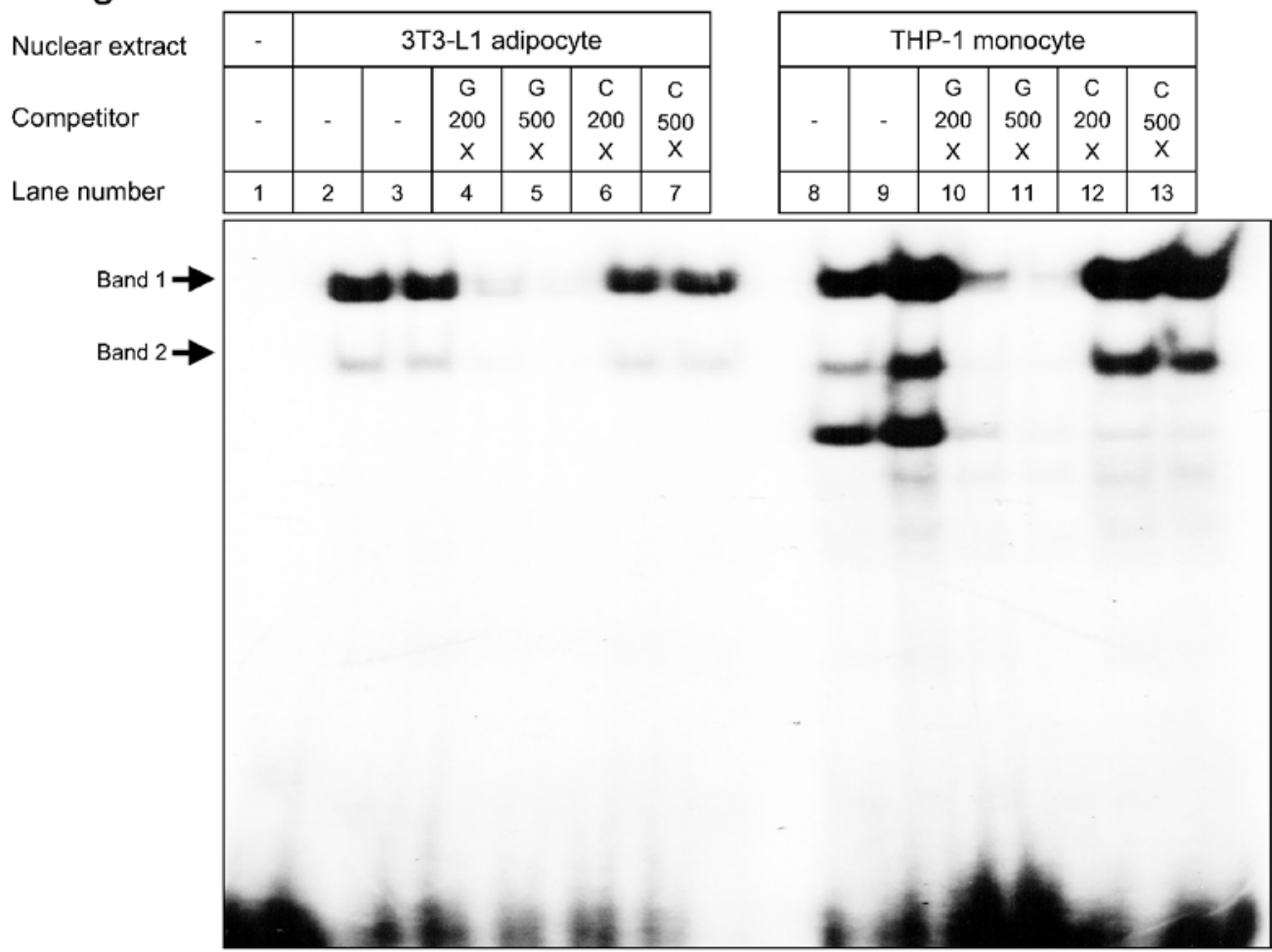

\section{b g. $-537 \mathrm{~A}>\mathrm{C}$}

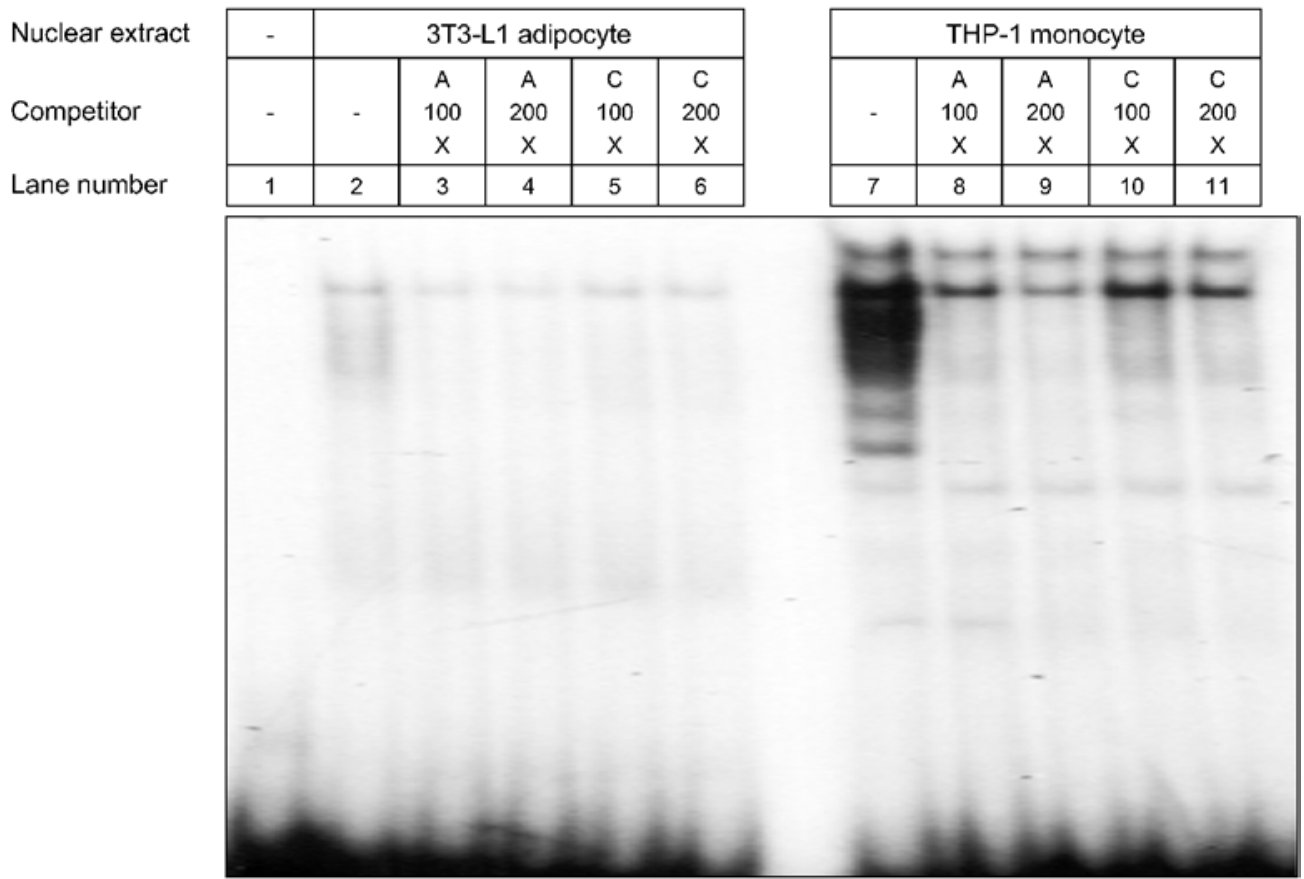

Fig. 1a. Binding of nuclear proteins to -420 and -537 regions of the resistin gene. The probe , -433 to $-406 \mathrm{bp}$ of the resistin gene containing $-420 \mathrm{G}$, was labelled as described in Materials and Methods. Lane 1: probe without nuclear proteins; lane 2: nuclear proteins $(5 \mu \mathrm{g})$ of 3T3-L1; lanes 3-7: nuclear proteins $(10 \mu \mathrm{g})$ of 3T3-L1; lane 8: nuclear proteins $(5 \mu \mathrm{g})$ of THP-1; lanes 9-13: nuclear proteins $(10 \mu \mathrm{g})$ of THP-1. Competitors were added to the probe at 200 - or 500 -fold molar excesses 